\title{
Construction and characterization of a bovine BAC library with four genome-equivalent coverage
}

\author{
André EGGEN ${ }^{\mathrm{a}, *}$, Mathieu GaUtier ${ }^{\mathrm{a}}$, \\ Alain Billaut ${ }^{\text {d }}$, Élisabeth Petit ${ }^{\mathrm{a}}$, Hélène Hayes ${ }^{\mathrm{a}}$, \\ Pascal LAurent ${ }^{\mathrm{a}}$, Catherine URBAN ${ }^{\mathrm{b}}$, \\ Martha Pfister-Genskow ${ }^{\mathrm{c}}$, Ken EILERTSEN ${ }^{\mathrm{c}}$, \\ Michael D. BISHOP \\ ${ }^{a}$ Laboratoire de génétique biochimique et de cytogénétique, \\ Département de génétique animale, Institut national de la recherche agronomique, \\ 78352 Jouy-en-Josas Cedex, France \\ ${ }^{\mathrm{b}}$ Fondation Jean Dausset, Centre d'étude du polymorphisme humain, \\ 27 rue Juliette Dodu, 75010 Paris, France \\ ${ }^{\mathrm{c}}$ Infigen Inc, 1825 Infinity Drive, DeForest, WI 53532, USA \\ d Molecular Engines Laboratories, 20 rue Bouvier, 75011 Paris, France
}

(Received 21 March 2001; accepted 16 May 2001)

\begin{abstract}
A bovine artificial chromosome (BAC) library of 105984 clones has been constructed in the vector pBeloBAC11 and organized in 3-dimension pools and high density membranes for screening by PCR and hybridization. The average insert size, determined after analysis of 388 clones, was estimated at $120 \mathrm{~kb}$ corresponding to a four genome coverage. Given the fact that a male was used to construct the library, the probability of finding any given autosomal and $\mathrm{X}$ or Y locus is respectively 0.98 and 0.86 . The library was screened for 164 microsatellite markers and an average of 3.9 superpools was positive for each PCR system. None of the 50 or so BAC clones analysed by FISH was chimeric. This BAC library increases the international genome coverage for cattle to around 28 genome equivalents and extends the coverage of the ruminant genomes available at the Inra resource center to 15 genome equivalents.
\end{abstract}

bovine / BAC library / mapping

\section{INTRODUCTION}

In cattle, numerous reports have identified genomic regions corresponding to economically important traits $[3,5,7]$ based on low to medium density marker maps. The density of these maps, however, is not sufficient to identify DNA

\footnotetext{
* Correspondence and reprints

E-mail: eggen@jouy.inra.fr
} 
variations responsible for genetic variation. Moreover, successful implementation of Marker Assisted Selection (MAS) programs and the generation of transgenic and knockout cattle will benefit from greater characterization of the bovine genome. Identification of DNA variations using fine mapping and positional cloning strategies, increasing the density of region-specific markers, and continued characterization of the genome for the production of genetically modified cattle requires the development of additional tools. A highly valuable tool procedure has been developed to generate large genomic DNA inserts with an acceptable genomic fidelity in a bacterial artificial chromosome (BAC) library to obtain complete coverage of the genome.

In addition to increased clone fidelity and a low level of cloning artefacts, BAC DNA can be more easily separated from the host's DNA. Consequently, BACs provide an excellent template for shotgun sequencing strategies and have become the main sequence-ready clone ressources for use in large-scale mapping and sequencing efforts. Individual clones often contain complete genes embedded in their genomic environment. The clones can thus be used for functional studies in cell lines or transgenic applications.

In this paper, we present the construction and extensive characterization of another bovine BAC library [1,2,11,13] containing 105984 clones with an average size of $120 \mathrm{~kb}$, which corresponds to about four genome equivalents. PCR-based screening and fluorescence in situ hybridisation (FISH) were performed in order to estimate the quality of the library.

\section{MATERIAL AND METHODS}

\subsection{DNA preparation}

A cell line derived from the genital ridge of a male fotus from a high ranking holstein bull was used to prepare $100 \mu \mathrm{L}$ DNA plugs embedded in low-melting agarose $(0.5 \%)$ in PBS at a concentration of about $2 \times 10^{6}$ cells per plug $(10 \mu \mathrm{g})$. The plugs were incubated twice in buffer containing proteinase $\mathrm{K}(1 \mathrm{mg} \cdot \mathrm{mL})$, EDTA (0.5 M, pH 8.5) and N-Lauryl-Sarcosine (1\%) at $55^{\circ} \mathrm{C}$ for $24 \mathrm{~h}$. After inactivation of the proteinase $\mathrm{K}$ in PMSF $(40 \mu \mathrm{g} \cdot \mathrm{mL})$ for $30 \mathrm{~min}$, the plugs were rinsed twice in Tris $10 \mathrm{mM}$, EDTA $1 \mathrm{mM}$ (TE 10-1) for $30 \mathrm{~min}$ and stored in EDTA ( $50 \mathrm{mM}, \mathrm{pH} 8.0$ ) for up to 2 months at $4{ }^{\circ} \mathrm{C}$.

\subsection{BAC vector preparation}

pBeloBAC11 was kindly provided by H. Shizuya, Department of Biology, California Institute of Technology (Pasadena, Calif.). Preparation of pBeloBAC11 was carried out as described [12]. 


\subsection{Partial digestion with HindIII}

Partial digestion was carried out on plugs, each containing approximately $10 \mu \mathrm{g}$ of high-molecular-weight DNA, after three 1-h equilibration steps in $10 \mathrm{~mL}$ of $1 \mathrm{X}$ HindIII digestion buffer (Boehringer Mannheim, Germany). The buffer was then removed and replaced by an ice-cold enzyme buffer $(1 \mathrm{~mL} / \mathrm{plug})$ containing $20 \mathrm{U}$ of HindIII (Boehringer). After a $2 \mathrm{~h}$ incubation on ice, the plugs were transferred to a $37^{\circ} \mathrm{C}$ water bath for $20 \mathrm{~min}$. Digestions were stopped by adding $10 \mathrm{~mL}$ of glacial EDTA $0.25 \mathrm{M}(\mathrm{pH} 8)$.

\subsection{Size selection}

Partially digested DNA in the plugs was subjected to contour-clamped homogeneous electric field (CHEF) electrophoresis on a $1 \%$ low-melting point agarose gel, using a DR III apparatus (Biorad, Hercules, Calif.) in 1X Trisacetate-EDTA buffer at $12{ }^{\circ} \mathrm{C}$, with a ramp from 5 to $15 \mathrm{~s}$ at $6 \mathrm{~V} / \mathrm{cm}$ for $16 \mathrm{~h}$. Agarose slices corresponding to size ranges from 75 to $100 \mathrm{~kb}, 100$ to $120 \mathrm{~kb}$, 120 to $150 \mathrm{~kb}, 150$ to $180 \mathrm{~kb}$ were excised from the gel and stored in TE at $4{ }^{\circ} \mathrm{C}$.

\subsection{Ligation and transformation}

Agarose slices containing the fractions were melted at $65^{\circ} \mathrm{C}$ for $10 \mathrm{~min}$ and digested with Gelase (Epicentre Technologies, Madison, Wis.) using $1 \mathrm{U}$ per $100 \mathrm{mg}$ of gel slice. Then 10 to $100 \mu \mathrm{g}$ of each size selected DNA were ligated in a molar ratio of 1:5 to 1:10 to HindIII- digested, dephosphorylated pBeloBAC11, using $10 \mathrm{U}$ of T4 DNA ligase (New England Biolabs, Beverly, Mass) at $12{ }^{\circ} \mathrm{C}$ for $36 \mathrm{~h}$. Ligation mixtures were heated at $65^{\circ} \mathrm{C}$ for $15 \mathrm{~min}$ and then drop-dialysed against 0.5X Tris-EDTA, using VS $0.025 \mu \mathrm{m}$ membranes (Millipore, Bedford, Mass.). Fresh electrocompetent E. Coli DH10B cells [9] were harvested from $200 \mathrm{~mL}$ of mid-log phase cultures grown in SOB medium, washed twice in ice-cold water with the same volume of culture and once in $50 \mathrm{~mL}$. Finally, cells were resuspended in ice-cold water to an optical density of 150 at $550 \mathrm{~nm}$.

$1-2 \mu \mathrm{L}$ of ligation mix was used to transform $30 \mu \mathrm{L}$ of electroporation competent E. Coli DH10B cells in an Easyject Plus electroporator (Equibio Kent, U.K.) with settings of $2.5 \mathrm{kV}, 25 \mu \mathrm{F}$ and $99 \Omega$, in 2-mm-wide electroporation cuvettes. After electroporation, the cells were resuspended in $1 \mathrm{~mL}$ of SOC medium, allowed to recover for $45 \mathrm{~min}$ at $37^{\circ} \mathrm{C}$ with gentle shaking, and then plated on LB agar containing chloramphenicol $(12.5 \mu \mathrm{g} \cdot \mathrm{mL})$, 5-bromo-4-chloro-3-indolyl-B-D-galactopyranoside (X-Gal, $50 \mu \mathrm{g} \cdot \mathrm{mL})$, and isopropyl- $\beta$-D-thiogalactopyranoside (IPTG, $25 \mu \mathrm{g} \cdot \mathrm{mL}$ ). The plates were incubated $20 \mathrm{~h}$ and recombinant white colonies were then manually picked in MEGA 96-well microtiter plates, each well containing $1.2 \mathrm{~mL} \mathrm{LB}$ with $10 \%$ 


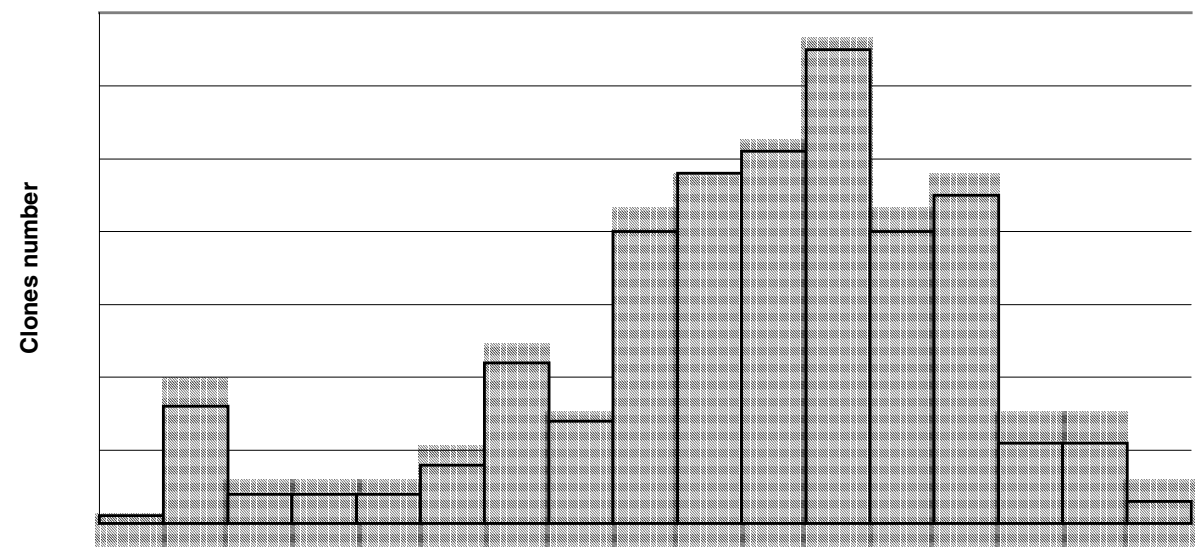

Insert size in $\mathbf{k b}$

Figure 1. Distribution of insert sizes in the bovine BAC library for a total of 388 clones analysed.

glycerol (w:v) and $12.5 \mu \mathrm{g} \cdot \mathrm{mL}$ chloramphenicol. After an 18-20 h incubation at $37^{\circ} \mathrm{C}$ with vigorous shaking, three copies of each 96-well microtitre plate were prepared and stored at $-80^{\circ} \mathrm{C}$ at different locations. Superpools of 24 plates and pools of individual plates (24), 12 columns and 8 rows were prepared by mixing respectively $300 \mu \mathrm{L}$ and 3 times $120 \mu \mathrm{L}$ of the bacteria culture. The different pools were collected manually. For each pool, bacteria were then pelleted, resuspended in TE, and the DNA was prepared by microwave boiling as described [8].

\section{RESULTS AND DISCUSSION}

Forty-six superpools were prepared corresponding to 105984 clones. The average insert size was determined by field inversion gel electrophoresis (FIGE) after digestion with NotI. A total of 388 clones was selected with insert sizes ranging from $6-225 \mathrm{~kb}$ and a mean size of $120 \mathrm{~kb}$ (Fig. 1). Less than $2 \%$ of the clones were considered as empty. Assuming that the bovine genome contains $3 \times 10^{9} \mathrm{bp}$, the total library corresponds to four genome-equivalents. Therefore the probability of finding any given autosomal locus in the library is 0.98 and given the fact that a male was used to construct the library, the probability of finding any given $\mathrm{X}$ or $\mathrm{Y}$ locus is 0.86 .

The BAC library was screened by PCR with primers for 164 microsatellite markers and genes and an average of 3.9 superpools were positive for each PCR system. Only one microsatellite was not found in the library. The library was also successfully screened for the 31 marker genes of the Texas standard 
nomenclature of the bovine karyotype [4], providing an accurate set of BAC clones which were used to resolve chromosome identification problems $[4,6]$. Fluorescence in situ hybridisation was performed as described [6] for over 50 BAC clones: none of the clones was chimeric.

Recently, the entire BAC library was spotted on high density membranes and transferred to 384 well-plates in order to permit screening of the library by hybridisation, in addition to PCR screening.

The bovine BAC library described in this publication contributes to increasing the genome coverage for cattle. Added to the already existing BAC libraries of 2.7 [1], 6 [2], 10 [11] and 5 [13] genome equivalents, the total coverage of the bovine genome represented in BAC libraries is around 28. Added to the bovine YAC, ovine BAC [10] and goat BAC [8] libraries hosted at Inra, this gives a 15 genome-equivalent coverage of the ruminant genomes available through the Inra resource center (http://www-dga.jouy.inra.fr/grafra/).

\section{ACKNOWLEDGEMENTS}

We wish to thank François Piumi for his helpful contribution to the production of high density membranes.

\section{REFERENCES}

[1] Buitkamp J., Kollers S., Durtewitz G., Fries R., Welzel K., Schäfer K., Kellermann K., Lehrach H., Construction and characterization of a gridded cattle BAC library, Anim. Genet. 31 (2001) 347-351.

[2] Cai L., Taylor J.F., Wing R.A., Gallagher D.S., Woo S.S., Davis S.K., Construction and characterization of a bovine bacterial artificial chromosome library, Genomics 29 (1995) 413-425.

[3] Charlier C., Farnir F., Berzi P., Vanmanshoven P., Brouwers B., Vromans H., Georges M., Identity-by-descent mapping of recessive traits in livestock: application to map the bovine syndactyly locus to chromosome 15, Genome Res. 6 (1996) 580-589.

[4] Gautier M., Laurent P., Hayes H., Eggen A., Development and assignment of bovine specific PCR-system for the Texas nomenclature marker genes and isolation of homologous BAC probes, Genet. Sel. Evol. 33 (2001) 191-200.

[5] Georges M., Andersson L., Livestock genomics comes of age, Genome Res. 6 (1996) 907-921.

[6] Hayes H., DiMeo G.P., Gautier M., Laurent P., Eggen A., Iannuzzi L., Localization by FISH of the 31 Texas nomenclature type I markers to both $\mathrm{Q}$ and R-banded bovine chromosomes, Cytogenet. Cell Genet. 90 (2000) 315-320.

[7] Riquet J., Coppieters W., Cambisano N., Arranz J.J., Berzi P., Davis S.K., Grisart B., Farnir F., Karim L., Mni M., Simon P., Taylor J.F., Vanmanshoven P., Wagenaar D., Womack J.E., Georges M., Fine-mapping of quantitative trait loci 
by identity by descent in outbred populations: application to milk production in dairy cattle, Proc. Natl. Acad. Sci., USA 96 (1999) 9252-9257.

[8] Schibler L., Vaiman D., Oustry A., Guinec N., Dangy-Caye A.L., Billault A., Cribiu E.P., Construction and extensive characterization of a goat bacterial artificial chromosome library with threefold genome coverage, Mamm. Genome 9 (1998) 119-124.

[9] Sheng Y., Mancino V., Birren B., Transformation of Escherichia coli with large DNA molecules by electroporation, Nucl. Acids. Res. 23 (1995) 1990-1996.

[10] Vaiman D., Billault A., Tabet-Aoul K., Schibler L., Vilette D., Oustry-Vaiman A., Soravito C., Cribiu E.P., Construction and characterization of a sheep library of three genome equivalents, Mamm. Genome 10 (1999) 585-587.

[11] Warren W., Smith T.P.L., Rexroad III C.E., Fahrenkrug S.C., Allison T., Shu C.L., Catanese J., De Jong P.J., Construction and characterization of a new bovine bacterial artificial chromosome library with 10 genome-equivalent coverage, Mamm. Genome 11 (2000) 662-663.

[12] Woo S.S., Jiang J., Gill B.S., Paterson A.H., Wing R.A., Construction and characterization of a bacterial artificial chromosome library of Sorghum bicolor, Nucl. Acids Res. 22 (1994) 4922-4931.

[13] Zhu B., Smith J.A., Tracey S.M., Konfortov B.A., Welzel K., Schalkwyk L.C., Lehrach H., Kollers S., Masabanda J., Buitkamp J., Fries R., Williams J.L., Miller J.R., A 5x genome coverage bovine BAC library: production, characterization, and distribution, Mamm. Genome 10 (1999) 706-709.

To access this journal on line: www.edpsciences.org 